\title{
GENETIC STUDIES ON SOME ECONOMIC TRAITS IN RABBITS 1-LITTER SIZE AND LITTER WEIGHT TRAITS
}

\author{
AMAL M. HEKIL ${ }^{1}$, G. M. GEBRIEL ${ }^{2}$, A. A. ENAB ${ }^{2}$, I. A. HAMODA ${ }^{1}$ \\ AND F. H. ABDOU ${ }^{2}$
}

1 Animal Production Research Institute, ARC, Dokki, Giza

2 Faculty of Agriculture, Menofiya University

(Manuscript received 29 October 2008)

\begin{abstract}
The main objective of the present study is to estimate some genetic aspects such as heritabilities, genetic and phenotypic correlations among litter size and weight traits, genetic gain and heterotic effects of (NZW) and (Cal) rabbits and their crosses. Results obtained could be summarized as follows:

Heritability estimates for litter traits were high and moderate of both NZW and Cal rabbits. All the possible genetic correlations among litter traits in both NZW and Cal rabbits were positive and moderate to high values. All litter traits studied were higher in (Cal) buck $\times(N Z W)$ doe rabbits than those of other mating groups (NZW buck $x$ Cal doe). The Cal sired mating groups produced litters with larger size (litter size at birth) and heavier weight (litter weight at birth and litter weight at weaning) as compared to NZW sired ones. Crossbreeding between NZW and Cal rabbits was associated with a significant positive heterotic effect on all litter traits studied. Direct heterotic effect was significant $(P<0.01)$ on LSB, NBA, LSW, LWB and LWW. Maternal additive effect in Cal rabbits was significant $(P<0.05$ or $P<0.01)$ for $L S W$, LWB and LWW and consequently could be used as a breed of sire in crossbreeding programs when using both NZW and Cal rabbits. Generally, the results of the present study may encourage the breeders to improve most of the litter traits.
\end{abstract}

\section{INTRODUCTION}

Heterosis among crosses is due to dominance of gene action at many loci. Crossbreeding is often applied to improve both quantity and quality of economic traits in rabbits. Carregal (1980) observed that mating between Californian (Cal) bucks and New Zealand White (NZW) does increased total number of born alive, litter size at weaning and litter weight at weaning in the crosses. Milk production of the crossbred does was increased when compared to purebred Cal does.

Lukefahr et al. (1983) compared superiority of NZW maternity to that of Cal in pre-weaning litter traits. They noted that litter size at weaning was largely dependent upon maternal care that was provided by does to their kits during lactation period.

Crossbreeding has an advantage over the synthesis of breeds in utilizing the breed differences due to the expected segregation along with recombination of genes (Dickerson, 1992). These differences have important potential sources of genetic improvement in the efficiency of human food production from rabbits through the 
expansion of superior breeds, the gains in performance from complementary breed effects and heterosis in crossbreeding, and the development of superior new breeds from selected combinations of several breeds (Hanafi and Iarqi, 2001).

\section{MATERIALS AND METHODS}

This experiment was carried out at the Rabbit Experimental Farm, Poultry Production Department, Faculty of Agriculture, Menufiya University, Shibin El-Kom, Egypt. The aim of this work is study some genetic aspects such as heritability estimates, genetic and phenotypic correlations among litter traits, genetic gain and heterotic effects of New Zealand White (NZW) and Californian (Cal) rabbits and their crosses. Sixteen bucks ( 8 NZW and 8 Cal) and 48 doe (24 NZW and 24 Cal) were mated in two ways in order to produce a generation of two pure breeds and their crossbreds. They represent different breed groups, New Zealand White (NZW) and Californian (Cal) purebred as well as Cal $\mathrm{x} \quad \mathrm{NZW}$ and NZW $\mathrm{X}$ Cal reciprocal crossbreds.

At the start of the experiment, the rabbits were healthy and free of internal and external parasites. The males and females were housed separately in individual-wired cages. The cage of each doe was provided with a metal nest box for kindling and nursing its progeny during the sucking period. Hygiene precaution was taken regularly. Mating started in October till the end of April. Each doe was transferred to the buck cage to be mated according to the mating plan of the experiment. Each doe was palpated after 12 to 14 days to determine pregnancy. The doe which failed to conceive was remitted to the same buck every other day until a service was observed. The nest boxes were supplied with rice straw on the 22nd day of pregnancy to provide a comfortable and warm nest for the young.

Rabbits of nearly similar age were housed in one hutch with a maximum of 10 to 12 individuals. They were housed in galvanized wire cage batteries $(60 \times 50 \times 40$ $\mathrm{cm}$.) Nipple drinkers and feeders were provided to each cage. Each doe was housed separately in a cage with nest box ( $40 \times 20 \times 20 \mathrm{~cm}$ ). Rabbits were kept as possible under the same environmental and managerial conditions.

Rabbits were fed ad libitum and ration was offered two times daily while fresh water was available all times. The ration contained $19.0 \%$ crude protein, $10.0 \%$ crude fiber and $2800 \mathrm{DE} \mathrm{Kcal/Kg}$ ration.

Data were collected on doe litter traits including litter size at birth (LSB), number born alive (NBA), litter size at weaning (LSW at 30 days), litter weight at birth (LWB) and litter weight at weaning (LWW) recorded to the nearest gram. Records of litters at kindling were taken within $12 \mathrm{~h}$ of kindling. 


\section{Statistical analysis}

The analysis of variance of these data was obtained according to Harvey (1990).

The following model was used for analyzing:

$$
Y_{i j k}=\mu+B_{i}+P_{j}+(B P)_{i j}+e_{i j k}
$$

Where :

$Y_{\mathrm{ijk}}=$ Observation on the $\mathrm{i}^{\mathrm{jk}}$ rabbit.

$\mu=$ Overall mean, common element to all observations. $B_{i}=$ Effect of the $i^{\text {th }}$ breed.

$P_{j}=$ Effect of $j^{\text {th }}$ parity. (BP) ${ }_{i j}=$ Interaction effect between the $i^{\text {th }}$ breed and $j^{\text {th }}$ parity .

$\mathrm{e}_{\mathrm{ijk}}=$ Random error component assumed to be normally distributed.

\section{Heritability estimates}

Each buk from NZW and Cal rabbits mated with three does within the same breed. LSB produced from 5.25 and 4.90 parities as average were about 89.64 and 86.81 in NZW and Cal rabbits, respectively. Heritability was estimated by paternal half sib method according to Harvey (1990) with the following equation:-

$$
h_{s}^{2}=\frac{4 \sigma_{s}^{2}}{\sigma_{s}^{2}+\sigma_{e}^{2}}
$$

Where: $\sigma^{2} s=$ Sire variance component $\quad \sigma^{2} e=$ Residual variance component

\section{Genetic and phenotypic correlations}

Genetic and phenotypic correlations were estimated according to Harvey (1990) with the following equation:-

$$
\mathrm{r}_{\mathrm{Gsxy}}=\frac{\operatorname{cov} \cdot s_{x y}}{\sqrt{v_{s_{x}} \cdot v_{s_{y}}}} \quad \mathrm{r}_{\mathrm{pxy}}=\frac{\operatorname{cov} p_{x y}}{\sqrt{v_{p_{x}} \cdot v_{p y}}}
$$

\section{Which:}

$r_{G s x y}=$ Genetic correlation between two considered traits ( $x$ and $\left.y\right)$,

Cov. $\mathrm{s}_{\mathrm{xy}}=$ Covariance of sire component between two traits,

$v_{s_{x}}=$ Variance of sire component for the trait $\mathrm{x}$,

$v_{s_{y}}=$ Variance of sire component for the trait $\mathrm{y}$,

$r_{\mathrm{pxy}}=$ Phenotypic correlation between two considered traits ( $\mathrm{x}$ and $\left.\mathrm{y}\right)$,

$\operatorname{cov} p_{x y}=$ Phenotypic covariance between two traits,

$v_{p_{x}}=$ Phenotypic variance for the trait $\mathrm{x}$

$v_{p_{y}}=$ Phenotypic variance for the trait $\mathrm{y}$.

\section{Analysis for crossbreeding data}

Crossbreeding effects (purebred difference, direct heterotic effect, maternal additive effect and direct additive effect) on different traits were estimated according to the genetic model shown in Table 1 according to Dickerson (1992). 
Table 1. Genetic model of analysis for crossbreeding data.

\begin{tabular}{|c|c|c|c|c|}
\hline \multirow{2}{*}{ Item } & \multicolumn{4}{|c|}{ Genotype } \\
\cline { 2 - 5 } & NZW & Cal & NZW (M) x Cal (F) & Cal (M) X NZW (F) \\
\hline Purebred differences & 1 & -1 & 0 & 0 \\
Direct heterosis effect & -1 & -1 & 1 & $1 /$ (Devisor 2) \\
Maternal additive effect & 0 & 0 & -1 & 1 \\
Direct additive effect & 1 & 1 & 1 & $-1 /$ (Devisor 2) \\
\hline
\end{tabular}

$\mathrm{M}$ : male $\mathrm{F}$ : female

*Buck or sire breed is listed before doe or dam breed.

Such genetic model permits to derive a selected set of contrasts (Harvey, 1987 i.e. purebred difference, heterotic effect, maternal additive effect and direct additive effect). The following linear contrast of mating group least-squares means were computed to quantify differences alternates attributable to sire breed, dam breed and direct heterotic effects as follows:

\section{Purebred differences}

$$
\left(G^{i} N Z W+G^{m} N Z W\right)-\left(G^{I} C a l+G^{m} C a l\right)=(N Z W+N Z W)-(C a l+C a l)
$$

\section{Direct heterotic effect or direct hetrosis (units)}

$$
\mathrm{H}^{\mathrm{i}}(\mathrm{NZW} \times \mathrm{Cal})=[(\mathrm{NZW} \times \mathrm{Cal}+\mathrm{Cal} \times \mathrm{NZW})-(\mathrm{NZW} \times \mathrm{NZW}+\mathrm{Cal} \times \mathrm{Cal})]
$$

Maternal additive effect (i.e. reciprocal crossbred difference)

$$
\left(G^{m} N Z W-G^{m} \text { Cal }\right)=[(N Z W \times C a l)-(C a l \times N Z W)]
$$

\section{Direct additive effect (i.e. breed group of sire differences)}

$\left(G^{i} \mathrm{NZW}-\mathrm{G}^{\mathrm{i}} \mathrm{Cal}\right)=[(\mathrm{NZW} \times \mathrm{NZW})+(\mathrm{NZW} \times \mathrm{Cal})]-[(\mathrm{Cal} \times \mathrm{Cal}) \times(\mathrm{Cal} \times \mathrm{NZW})]$

\section{Where}

$\mathrm{G}^{\mathrm{i}}$ and $\mathrm{G}^{\mathrm{m}}$ represent direct additive and maternal additive effects, respectively, of the subscripted genetic group. Each single degree of freedom contrast was tested for significance with the students t-test.

\section{Genetic gain}

The expected genetic gains $(\Delta \mathrm{GE})$ were calculated according to the following formula. $\Delta \mathrm{GE}=\mathrm{S} \mathrm{h}{ }^{2}$

Where: $S=$ Selection differentials. $\quad h^{2}=$ Heritability of the traits.

\section{RESULTS AND DISCUSSION}

\section{Paternal heritability}

Heritability estimates in the present study were moderate to high. The estimates of NZW rabbits were $0.56,0.36,0.52$ and 0.96 for LSB, NBA, LSW and LWW, respectively. In Cal rabbits, the estimates were $0.12,0.27,0.86$ and 0.47 for LSB, NBA, LWB and LWW, respectively (Table 2). These results indicated that the 
direct additive variance is a considerable importance, and consequently litter traits studied of both NZW and Cal rabbits could be improved by selection of sires based on the performance of their progenies and also selection for does and dams.

These estimates agree with those reviewed for litter traits estimated by Abdou et al., 2006. On the other hand, low heritability values of litter traits were obtained by Ghoneim, 2004.

Heritability estimates in the present study for LSB of Cal rabbits were low, and the same result was obtained by Ghoneim (2004). He explained that the low estimates of heritability for LSB might be due to the large maternal effects and or variation due to permanent environment which could have masked any additive genetic variance (i.e. due to increasing non-additive genetic effects).

\section{Genetic and phenotypic correlations}

\section{a. Genetic correlation $\left(r_{G}\right)$}

All possible genetic correlation estimates among litter traits (LSB, NBA, LWB, LSW and LWW) in both NZW and Cal rabbits were positive and high values (Table 3). The $r_{G}$ estimates ranged from 0.609 between LWB and LWW to 0.917 between LSB and NBA in NZW rabbits. The increase in LWB might be accompanied by an improvement in LWW. Genetic improvement in LWB was accompanied by an increase in LSW, but usually the increase in litter weight is associated with decrease in litter size. High genetic correlation estimates of LWW indicated that heavy LWB have high LWW. These results agreed with the results obtained by Ghoneim, 2004 and Abdou et al. 2006.

\section{b. Phenotypic correlations $\left(r_{p}\right)$}

All the possible phenotypic correlation estimates among litter traits were positive and mostly moderate or high magnitude in both NZW and Cal rabbits. Negative phenotypic correlation was found only between NBA and LWB in NZW, and between LSW and LWW in Cal rabbits (Table 3). The values of phenotypic correlation ranged between -0.734 (NBA and LWB) and 0.939 (LWB and LWW) in NZW breed, while, they ranged between -0.125 (LSW and LWW) and 0.933 (NBA and LWB) in Cal breed. Similar results were obtained by Enab, 2001 and Abdou et al., 2006.

Sometimes, the environmental effects upon the two litter traits could be strong and positively correlated, and consequently, a positive a $r_{p}$ could be obtained. Therefore, it is clear that the $r_{\mathrm{p}}$ is not quite satisfactory indicator to expect correlated genetic response of litter traits under selection, the genetic correlation is the one estimate to be used for such prediction. 


\section{Genetic improvement}

It may be useful to show how much genetic gains would be expected if individual (mass) selection on a single trait was applied. The expected genetic gain for litter traits are presented in Table 4.

The expected genetic gain in NZW breed would be:

+0.15 young in (LSB), +0.05 young in (NBA).

+0.06 young in (LSW), $+141.71(\mathrm{~g})$ in (LWW).

The expected genetic gain in Cal breed would be:

+0.08 young in (LSB), +0.16 young in (NBA).

+22.35 (g) in (LWB), + 102.55 (g) in (LWW).

It is clear that, if one standard deviation of selection pressure is applied directly to litter size at birth, one can expect a genetic increase in LSB of 0.15 vs 0.08 young, NBA of 0.05 vs 0.16 young, LSW of 0.06 vs 0.00 young, LWB of 0.00 vs $22.35 \mathrm{~g}$ and LWW of 141.71 vs $102.55 \mathrm{~g}$ in both NZW and Cal rabbits, respectively. Similar results were obtained by Enab et al. (2000) who indicated that if one standard deviation of selection pressure is applied directly to litter size at birth, one can expect a genetic increase in litter size at birth of 0.20 and 0.38 young per litter in NZW and Cal rabbits, respectively. Similarly, with one standard deviation of selection pressure applied directly to number born alive, litter weight at birth, mean bunny weight at birth, litter size at weaning and litter weight at weaning, it can be expected to get genetic increases of 0.15 young, $10.87 \mathrm{~g}, 0.61 \mathrm{~g}, 0.14$ young and $43.33 \mathrm{~g}$ in NZW breed population and 0.29 young, $18.36 \mathrm{~g}, 1.57 \mathrm{~g}, 0.18$ young and $78.40 \mathrm{~g}$ in Cal breed, respectively. Moreover, the theoretical maximum rate of direct genetic progress in rabbit stocks selected only for litter size at birth and for litter size at weaning are 2.62 and $3.92 \%$ per generation in NZW breed, while, in Cal breed they are 6.02 and $5.77 \%$ per generation, respectively. Therefore, the expected direct selection gives good improvement in both litter size at birth and at weaning (Enab et al.,2000).

Also, the expected genetic gain in litter weight at weaning was moderate to high (Khalil and Afifi, 1988). Genetic trends were 0.05 and 0.16 weaned rabbits per generation for strains $A$ and $V$ selected on litter size at weaning, respectively (Estany et al., 1989). The expected direct genetic gain per generation in rabbits selected for litter size at weaning, litter weight at weaning or average progeny weight at weaning was estimated as 0.46 (10.02\% of the adjusted mean), $334 \mathrm{~g}(13.01 \%)$ and $17.01 \mathrm{~g}$ (2.94\%), respectively (Moura et al., 1991). 


\section{Crossbreeding and heterotsis}

\section{a. Mating groups effect}

Least square means of litter traits (LSB, NBA, LSW, LWB and LWW) produced from four mating groups during five parities are shown in Tables 5 and 6 . All means of litter traits studied were higher in Californian buck (Cal) $\times$ New Zealand White doe (NZW) rabbits than other mating groups. These findings agree with those reported by El-Badawy (2004). On the other hand, Oudah (1990) found that mating group effect on most litter traits studied was non-significant.

\section{b. Direct additive (buck breed) effect}

Contrast of buck-breed group effect represents one-half of the direct additive effect between New Zealand White and Californian breed groups, i.e.[ (NZW x NZW) $+(\mathrm{NZW} \times \mathrm{Cal})]-[(\mathrm{Cal} \times \mathrm{Cal})+(\mathrm{Cal} \times \mathrm{NZW})]$. The linear contrasts of direct additive effect for all litter traits were not significant (i.e. that effect was nearly similar in both breeds). Such similarity in direct additive (buck breed) effect between the two parental breeds was expected as the mating type effect on litter traits was also not significant.

However, Youssef (1992) reported that direct genetic effects on litter traits at birth and 21 days were in favour of New-Zealand White but not of Baladi Red and the reverse was true at weaning.

On the other hand, Zaky (2001) indicated that heterosis was insignificant for litter traits studied in crosses of NZW and Cal rabbits (litter size at birth and at weaning and litter weight at birth and at weaning), positive heterosis was obtained in individual birth weight, individual weaning weight, litter size at birth, average birth and weaning weight. He added that relatively small amount of heterosis was observed in the average weight of progeny at birth. It may be explained partly by the fact that birth weights in rabbits are negatively affected by the size of the litter at birth. Litter genetic variation between NZW and Cal might explain the litter heterosis that was obtained for litter traits.

\section{c. Maternal additive effects}

Difference between the reciprocal crossbreeds $\left(G^{m} N Z W-G^{m}\right.$ Cal) indicates the relative magnitude of maternal ability of both New Zealand White and Californian rabbit does. [ i.e. the linear contrast of (Cal x NZW) - (NZW - Cal) ].

Maternal additive effect was significant $(P<0.05)$ or highly significant $(P<0.01)$ for litter size at weaning, litter weight at birth and litter weight at weaning, while, not significant for litter size at birth and number born alive (Table 7). The same effect was found to be significant $(P<0.05)$ or highly significant $(P<0.01$ and $P<0.001)$ on number born alive and litter size at weaning (El-Desoki, 1991). Also, Youssef (1992) 
proved that doe breed effect on most litter traits (number born alive, litter size at 21 days, litter size at weaning, litter weight at birth, litter weight at 21 days, litter weight at weaning and pre-weaning litter gain) was significant $(P<0.05)$ or highly significant $(P<0.01$ and $P<0.001)$.

Mating of Californian bucks with New-Zealand White does gave larger and heavier of all litter traits compared with those of NZW ones. These findings agree with the results of Carregal, (1980) who observed that mating between Californian bucks and New-Zealand White does increased total number of born, litter size at weaning and litter weight at weaning in the crosses. Individual heterosis and favourable improved breeds may influence products of purbred NZW does.

\section{d. Crossbreeding and heterotic effect}

Estimates of direct heterosis contrasts for different litter traits presented in Table 7 indicate that crossbreeding between New-Zealand White and Californian rabbits was associated with significant positive heterotic effects on all litter traits studied. Direct heterotic effect was highly significant $(P<0.01)$ on $L S B, N B A, L S W$, LWB and LWW.

These results, in spite of the high significant values of heterotic effect, had evidence of superiority of the crossbred litters over those of the purebred parental breeds which was attributed by Afifi (1971) to the presence of inter-breed nonadditive genetic effects. Heterotic effects, in the Egyptian literature were evident in most of the crossbreeds for litter size (Yossef, 1992), litter weight (Afifi and Khalil, 1989) and mean bunny weight per litter at birth (Afifi, 1971).

Heterotic effect was lower at birth than at weaning for litter weight. This is expected since maternal and milking ability effects decreased with advance of litter age, and consequently, the non-additive genetic effects could express themselves later at weaning age more than earlier at kindling. Similar findings were obtained by Afifi and Khalil (1989).

Results of the present study could refer to the possibility of utilizing Californian rabbits as a terminal buck breed in crossbreeding programs when using Cal and NZW rabbits. 
Table 2 . Sire heritability $\left(\left(\mathrm{h}_{\mathrm{s}}^{2}\right)\right)$ for litter traits of both New-Zealand White and Californian rabbits.

\begin{tabular}{|c|c|c|}
\hline Litter traits & $\begin{array}{c}\text { New-Zealand White } \\
\text { Mean } \pm \text { S.E }\end{array}$ & $\begin{array}{c}\text { Californian } \\
\text { Mean } \pm \text { S.E }\end{array}$ \\
\hline LSB & $0.559 \pm 0.566$ & $0.122 \pm 0.310$ \\
NBA & $0.361 \pm 0.518$ & $0.274 \pm 0.395$ \\
LSW & $0.516 \pm 0.556$ & $\overline{0.860 \pm 0.719}$ \\
LWB & $0.964 \pm 0.629$ & $0.469 \pm 0.529$ \\
\hline
\end{tabular}

LSB: Litter size at birth, NBA: Number born a live, LSW: Litter size at weaning LWB: Litter weight at birth, LWW: Litter weight at weaning

Table 3 . Genetic $(r G)$ and phenotypic $(r P)$ correlations between litter traits in New Zealand White (NZW) and Californian (Cal) rabbits.

\begin{tabular}{|c|c|c|c|c|}
\hline \multirow{2}{*}{ Litter traits } & \multicolumn{2}{|c|}{ NZW } & \multicolumn{2}{|c|}{ Cal } \\
\cline { 2 - 5 } LSB\& & $\mathrm{r}_{\mathrm{G}}$ & $\mathrm{r}_{\mathrm{P}}$ & $\mathrm{r}_{\mathrm{G}}$ & $\mathrm{r}_{\mathrm{P}}$ \\
NBA & & & & \\
LSW & 0.917 & 0.451 & 0.816 & 0.809 \\
LWB & 0.735 & 0.207 & 0.768 & 0.447 \\
LWW & 0.759 & 0.822 & 0.632 & 0.510 \\
NBA\& & 0.669 & 0.504 & 0.615 & 0.462 \\
LSW & 0.792 & 0.521 & & \\
LWB & 0.812 & -0.734 & 0.848 & 0.718 \\
LWW & 0.701 & 0.513 & 0.768 & 0.933 \\
LSW\& & & & 0.770 & 0.760 \\
LWB & 0.713 & 0.418 & 0.681 & \\
LWW & 0.874 & 0.902 & 0.912 & -0.479 \\
LWB\& & & & & \\
LWW & 0.609 & 0.939 & 0.847 & 0.650 \\
\hline
\end{tabular}

LSB: Litter size at birth, NBA: Number born a live, LSW: Litter size at weaning LWB: Litter weight at birth, LWW: Litter weight at weaning 
AMAL M. HEKIL, et al., 


\section{REFERENCES}

1. Abdou, A. M., A. E. Khattab and A. E. Abou-Zeid. 2006. Genetic and phenotypic parameters of productive and reproductive traits in five rabbit breeds. Egypt. Poult. Sci., (26): 1241-1252.

2. Afifi, E. A. 1971. A study of some economical and productive characters in some breeds of rabbits and their corosses. Thesis, Ph.D. Fac. Agric. Ain-Shams Univ., Egypt.

3. Afifi, E. A. and M. E. Emara. 1984. Litter weight in local Egyptian and exotic breeds of rabbits and their crosses. Proc. 3rd World Rabbit. Congress, 4-8 April 1984, Rome, Italy, World Rabbit Sci. Association, Vol. QG1, pp. 126-135.

4. Afifi, E. A. and M. H. Khalil. 1989. Observations on purebred and crossbred litter of Giza white and Grey Giant Flanders rabbits in Egypt. J. Appl. Rabbit Res., 12: 273-277.

5. Campos, A. P., H. D. Rochambeau, R. Rouvier and B. Poujardieu. 1980. The rabbit selection scheme in Mexico: Objectives and primary results. Proceeding 2nd World Rabbit Congress, April 1980, Barcelona, Spain.

6. Carregal, R. D. 1980. Evaluation of heterosis, combing ability and maternal and reciprocal mating effects in rabbits. Proc. 2nd World Rabbit Congress, April 1980. Barcelona, Spain, carregal. R.D. (1981). Heterosis in growing crossbred rabbits. Revista de Sociedade Brasileira de Zootecnia, 10(4):594-603.

7. Dickerson, G. E. 1992. Manual for evaluation of breeds and crosses of domestic animals. Publications Division, FAO, Rome, Italy.

8. El-Badawy, F. E. A. 2004. Studies of some productive traits in rabbit. Thesis, M. Sc. Fac. Agric., Cairo, University, Egypt.

9. El-Desoki, A. E. M. 1991. Study of the Effect of Some Genetic and Environmental Factors Affecting Meat Yield From Some Foreign and Local Breeds of Rabbits and Their Crosses. Thesis, MSc. Fac. Agric., Mansoura Univ., Egypt.

10. El-Maghawry, A. M. 1990. Genetic and environmental factors affecting performance of broiler rabbits. Thesis, Ph. D., Fac. Agric., Zagazig Univ., Egypt.

11. El-Raffa, A. M. 2005. Genetic analysis for productive and reproductive traits of $\mathrm{V}$ line rabbits raised under Egyptian conditions. Egypt. Poult. Sci., (25):1217-1231.

12. Enab, A. A. 2001. Genetic evaluation of multi - trait selection indices for overall economic improvement in rabbit breeding programs. Egypt. Poult. Sci., 21 (1): 221-236. 
13. Enab, A. A., A. O. El-Weshahy and F. H. Abdou. 2000. Genetic analysis of some economic traits in rabbits. Egypt. J. Rabbit Sci., 10 (2): 327-339.

14. Estany, J., M. Baselga, A. Blasco and J. Camacho. 1989. Mixed model methodology for the estimation of genetic response to selection in litter size of rabbits. Livest. Prod. Sci., 21:67-75.

15. Garcia, F., M. Baselga, A. Blasco and J. Deltoro. 1982a. Genetic analysis of some productive traits in meat rabbits. I. Numeric traits. 2nd World Congress on Genetic Applied to livestock production, 4-8 October, Madrid, Spain, 7, 557-562.

16. Garcia, F., M. Baselga, A. Blasco and J. Deltoro. 1982b. Genetic analysis of some productive traits in meat rabbits. I. Ponderal traits. 2nd World Congress on Genetic Applied to livestock production, 4-8 October, Madrid, Spain, 7, 575-579.

17. Ghoneim, S. S. Y. 2004. Genetic parameters for some quantitative characters in Bouscat rabbits. Thesis, M. Sc., Fac. Agric., Ain Shams University, Egypt.

18. Hanafi, M. S. and M. M. Iraqi. 2001. Evaluation of purebreds, heterosis, combining abilities, maternal and sex - linked effects for some productive and reproductive traits in chickens. Second inter. Conf. Anim. Prod. \& Health in SemiArid Areas 4-6 Sept., 545-555.

19. Harvey, W. R. 1987. User's Guide for LSML 86, Mixed Model Least- squares and maximum likelihood computer program, Mimeo., Ohio State Univ., U.S.A.

20. Harvey, W. R. 1990. User's Guide for LSMLMW. Mixed Model Least- squares and maximum likelihood computer program-PC-Version 2, Ohio state Univ., Columbus, USA, (Mimeograph)

21. Khalil, M. H. and E. A. Afifi. 1988. Selection subindices for improving litter weight productivity of doe rabbits. Egypt. J. Rabbit Sci., 1 (2): 172-184.

22. Khalil, M. H., E. A. Afifi and A. E. H. Kadry. 1989. Genetic analysis of weight of doe rabbits during gestation and its phenotypic relationship with reproductive efficiency at kindling. J. Appl. Rabbit Res., 12: 445-51.

23. Khalil, M.H., E. A. Afifi, M. E. Emara and J. B. Owen. 1988. Genetic and phenotypic aspects of doe productivity in four breeds of rabbits. J. Agric. Sci., 110: 191-197.

24. Khalil, M.H., E. A. Afifi, Y. M. K. Youssef and A. F. Khadr. 1995. Heterosis, maternal and direct genetic effects for litter performance and reproductive interval in rabbits Crosses. World Rabbit Sci., 3 (3): 99-105.

25. Lukefahr, S. D. 1982. Evaluation of rabbit breeds and crosses for overall commercial productivity. Ph. D. Thesis, Oregon state University, Corvallis, USA. 
26. Lukefahr, S. D., W. D. Hohenbaken, P. R. Cheeke and N. M. Patton. 1983a. Characterization of straight bred and crossbred rabbits for milk production and associative traits. J. Anim. Sci., 57 (5): 1100-1107.

27. Lukefahr, S. D., W. D. Hohenbaken, P. R. Cheeke and N. M. Patton. 1983b. Doe reproduction and pre-weaning litter performance of straightbred and crossbred rabbits. J. Anim. Sci., 57 (5): 1090-1100.

28. Moura, A. S. A. M., R. Polastre and M. J. Carmelo. 1991. Genetic study of litter traits at weaning in selecta rabbits. J. Appl. Rabbit Res., 14: 222-227.

29. Oudah, S. M. 1990. Studies on some rabbit breeds and their crosses. Thesis, M. Sc., Fac. Agric., Mansoura, University, Egypt.

30. Youssef, M. K. 1992. The Productive Performance of Purebred and Crossbred Rabbits. Thesis, M. Sc., Fac. Agric., Moshtohor, Zagazig Univ., Banha Branch, Egypt.

31. Zaky, H. I. 2001. Effects of genetic and non-genetic factors on litter traits in crosses of two rabbit strains under desert conditions. Egypt. Poult. Sci., 21: 627640. 


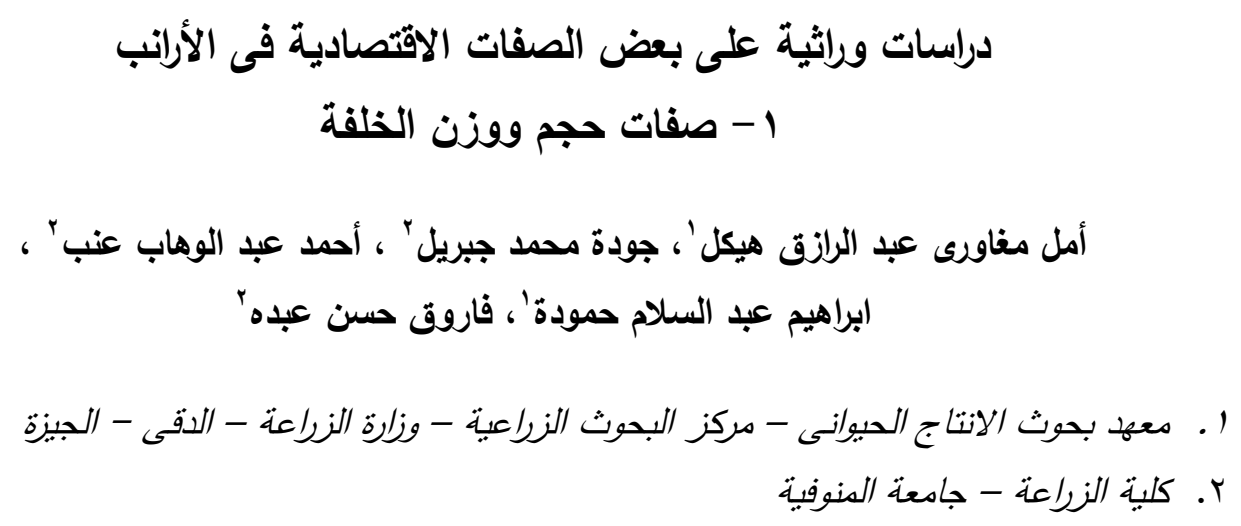

تم اجراء هذا العهل بهدف دراسـة بعض القياسـات الوراثيـة مثنل تقدير المكافىء الوراثى والأرنباط الوراثى والمظهرى والعائد الوراثى لكل من صفات حجم ووزن الولدة وكذلك دراسة تأثنير قوة الخلط فى نوعين من الأرانب الأجنبية وهما النيوزيلاندى الأبيض والكاليفورنيا وخليطهما. وأمكن تلخيص النتائج المتحصل عليها كما يلى:-

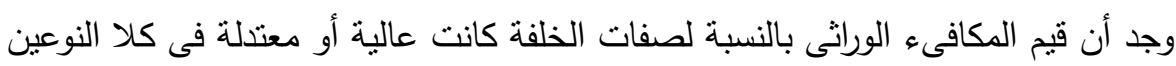

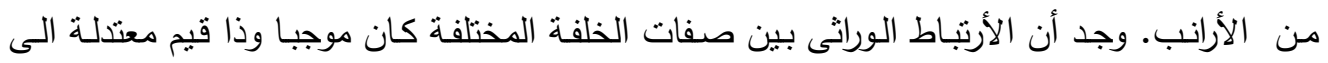
عالية فى كلا النوعين من الأرانب .وجد أن الأرتباط المظهرى بين صفات الخلفة المختلفة كان موجبا

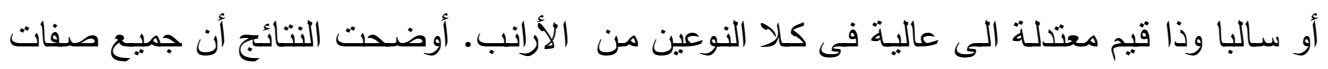

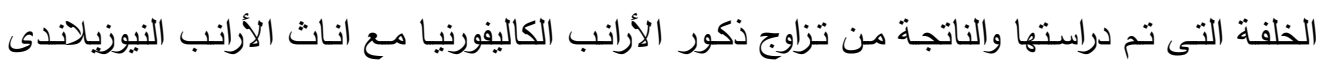

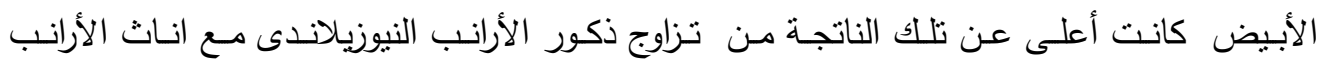

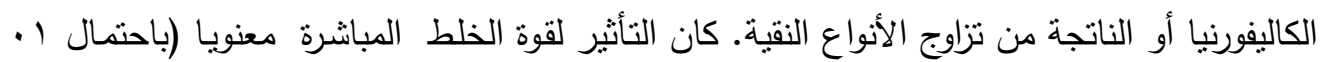

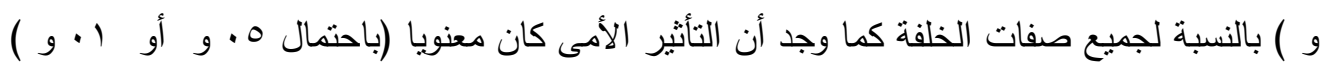

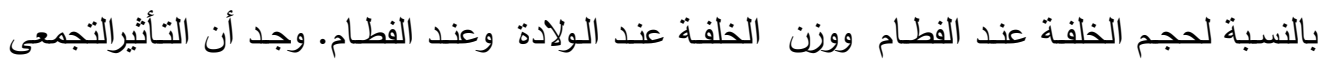
المباشر بالنسبة لجميع صفات الخلفة المدروسة كان غير معنويا. وعموما النتائج المتحصل عليها ولنا ربما تشجع المربيين لتحسين صفات الخلفة. 